Published in final edited form as:

Cancer Lett. 2008 February 18; 260(1-2): 209-215.

\title{
Vitamin D receptor polymorphisms and risk of epithelial ovarian cancer
}

\author{
Tess V. Clendenena, ${ }^{*}$, Alan A. Arslana,b,c, ${ }^{\star} \dagger$, Anne Zeleniuch-Jacquotte ${ }^{a, c}$, Kerstin \\ Enquist ${ }^{d}$, Isaac Wirgina ${ }^{a}$ Åsa Ågren $d$, Annekatrin Lukanova ${ }^{\mathrm{e}}$, Hubert Sjodind, Karen L. \\ Koeniga , Roy E. Shore ${ }^{f}$, Göran Hallmans ${ }^{d}$, Paolo Tonioloa,b,c, and Eva Lunding \\ aDepartment of Environmental Medicine, New York University School of Medicine, New York, NY 10016, \\ USA \\ bDepartment of Obstetrics and Gynecology, New York University School of Medicine, New York, NY 10016, \\ USA
}

cNew York University Cancer Institute, New York, NY 10016, USA

dDepartment of Public Health and Clinical Medicine/Nutritional Research, University of Umeå, Umeå, Sweden

eDivision of Cancer Epidemiology, German Cancer Research Center (DKFZ), Heidelberg, Germany

fRadiation Effects Research Foundation, Hiroshima, Japan

gDepartment of Medical Biosciences/Pathology, University of Umeå, Umeå, Sweden

\begin{abstract}
The vitamin $\mathrm{D}$ receptor (VDR) is a critical mediator of the cellular effects of vitamin $\mathrm{D}$. The associations between four common VDR polymorphisms (BSMI, APAI, TAQI, and FOKI) and risk of epithelial ovarian cancer (EOC) were assessed in a case-control study nested within two prospective cohorts. One hundred seventy incident cases of EOC and 323 individually-matched controls were genotyped. Overall, no associations were observed in genotype analyses. Haplotypes combining three SNPs in high linkage disequilibrium (BSMI, APAI, TAQI) were also not associated with risk. These observations do not support a role for BSMI, APAI, TAQI, and FOKI polymorphisms in epithelial ovarian cancer in a predominantly Caucasian population.
\end{abstract}

\section{Keywords}

Vitamin D receptor; genetic variants; ovarian neoplasms; epidemiology; prospective cohorts

\section{Introduction}

Ovarian cancer is the second most common cancer of the female reproductive system and the leading cause of female gynecological cancer death in the United States [1]. Although 5-10\%

\footnotetext{
†Corresponding author: Alan A. Arslan, MD, Department of Obstetrics and Gynecology, New York University School of Medicine, 550 First Avenue NBV-9E2, New York, NY 10016, USA, Phone: 1-212-263-7792, Fax: 1-212-263-8887, E-mail: akhmea01@med.nyu.edu.

These authors contributed equally to this work.

Publisher's Disclaimer: This is a PDF file of an unedited manuscript that has been accepted for publication. As a service to our customers we are providing this early version of the manuscript. The manuscript will undergo copyediting, typesetting, and review of the resulting proof before it is published in its final citable form. Please note that during the production process errors may be discovered which could affect the content, and all legal disclaimers that apply to the journal pertain.
} 
of cases are attributed to heredity, the etiology of this disease in the majority of cases remains unknown [2]. Ecological studies have shown substantial geographical variation in age-adjusted incidence rates of EOC that point to a possible role of vitamin D [3]. Incidence rates tend to be higher in North America and northern Europe, as compared to Asia and Africa suggesting an association with latitude [3,4]. Increasing latitude has also been associated with higher mortality within the United States [3,5]

Solar ultraviolet B (UVB) radiation is the primary initiator of the conversion of 7 dehydrocholesterol into cholecalciferol (vitamin $\mathrm{D}_{3}$ ) in the skin [6]. Additional sources of vitamin D include certain fish, fortified dairy products, and dietary supplements. Upon conversion or intake, vitamin $\mathrm{D}_{3}$ is metabolized to the active metabolite, 1-alpha,25dihydroxyvitamin $\mathrm{D}_{3}\left(1,25-\mathrm{diOH}-\mathrm{D}_{3}\right)$, which reduces proliferation and promotes differentiation and apoptosis via binding to the nuclear vitamin D receptor (VDR) [7] [6]. The VDR is present in both normal and malignant ovarian cells and works as an important transcriptional activator in the vitamin D pathway [7]. For example, deleterious mutations in the gene encoding the VDR cause 1,25-dihydroxyvitamin $\mathrm{D}_{3}$ resistant rickets, a rare monogenetic disease [8]. Less is known about the effects of more subtle genetic variation (polymorphisms) on VDR function. An important VDR polymorphism is FOKI (rs2228570) [9], a $\mathrm{T}$ to $\mathrm{C}$ transition which alters the transcription start site and forces downstream transcription initiation [10]. The resulting protein is three amino acids shorter and has higher transcriptional activity than the wild-type gene product [10]. The only previous study to date showed an increased risk of epithelial ovarian cancer for Caucasian women with the FOK1 minor allele $(\mathrm{OR}=2.2 ; 95 \% \mathrm{CI}=1.1-4.5)$ [11]. Less functional information is known about the common 3' single nucleotide polymorphisms (SNPs), BSMI (rs1544410) [12], APAI (rs7975232) [13], and TAQI (rs731236) [14], but they may be associated with a functional variant of the VDR or another related gene [10].

The objective of the present study was to examine the relationship between common VDR polymorphisms and risk of epithelial ovarian cancer in a collaborative effort between two prospective cohorts.

\section{Materials and methods}

\subsection{Study population}

The New York University Women's Health Study (NYUWHS) and the University of Umeå Northern Sweden Health and Disease Study (NSHDS) have been described in detail previously [15-17]. Aliquots of serum (NYUWHS) or plasma and buffy coat (NSHDS) have been stored at $-80^{\circ} \mathrm{C}$ since enrollment without thawing. Eligible cases included all invasive epithelial ovarian carcinomas diagnosed and confirmed as of November 1, 2005. Case ascertainment in the NYUWHS was determined by self report using regular follow-up questionnaires and through linkages with the National Death Index and state tumor registries. Medical records were obtained to verify information about reported events. NSHDS cases were determined through linkages to regional and national cancer registries and to all-cause mortality registries. As of November 2005, a total of 170 eligible EOC cases (71 from NYUWHS and 99 from NSHDS) were included in the current study.

For a majority of NYUWHS cases and for all NSHDS cases, two controls were selected at random for each case from the appropriate risk set. Seventeen cases from the NYUWHS cohort had only one eligible matched control. The risk set consisted of women who were alive and free of cancer at the time of diagnosis of the case and who matched the case on cohort, age at entry (within 6 months), date of blood donation (within 15 days), and number and dates of subsequent blood donations (if any). To be eligible, controls could not have had bilateral oophorectomy before the date of diagnosis of the matched case. Subjects reporting pregnancy 
or hormone use within 6 months of enrollment were not eligible for the NYUWHS cohort or for case-control selection from NSHDS. There were 323 eligible controls in total (125 from NYUWHS and 198 from NSDHS).

The institutional review boards of the New York University School of Medicine and the Regional Ethical Committee of the University of Umeå, Sweden, and the Swedish Data Inspection Board have reviewed and approved this study.

\subsection{Laboratory methods}

Genotyping was performed at the New York University School of Medicine. Laboratory personnel were unaware of the case-control status of samples and matched sets were run in the same batch. Blinded duplicates were discordant for only one (APA1 and FOK1) or two (BSM1 and TAQ1) out of 56 duplicates for each genotype.

DNA was extracted using QIAamp Midi or FlexiGene kits (QIAGEN, Inc., Valencia, CA) from NYUWHS and NSHDS samples, respectively. PCR amplification primers used were: for APA1 forward GGTGGGATTGAGCAGTGAG and reverse GGCACGGGGATAGAGAAGA, for BSM1 forward TTCCTGGGGCCACAGACA and reverse AATGTTGAGCCCAGTTCACGC, for TAQ1 forward TTCTTCTCTATCCCCGTGCC and reverse GGCAGCGGATGTACGTCT, and for FOK1 forward CTCTGACCGTGGCCTGCTT and reverse AAGTGCTGGCCGCCATTG. For all four SNPs, PCR conditions were $95^{\circ} \mathrm{C}$ for 5 minutes, $95^{\circ} \mathrm{C}$ for 30 seconds, $65^{\circ} \mathrm{C}$ for 30 seconds, $72^{\circ} \mathrm{C}$ for 30 seconds, (40-45 cycles for latter three steps), then $72^{\circ} \mathrm{C}$ for 7 minutes.

All PCR products were genotyped using pyrosequencing technology on the PSQ HS 96 (Biotage, Uppsala, Sweden) using the following sequencing primers: for APA1 GGATTGAGCAGTGAGG, for BSM1 - AGCCTGAGTATTGGGA, for TAQ1 GGTCCTGGATGGCCT, and for FOK1 - GGCCGCCATTGCCTC.

Complete genotypes for all four SNPs were achieved for 483 of the 493 participants. Seven participants were missing genotypes at one or two SNP loci, and three participants (a case and her matched controls) did not have any DNA available for genotype analysis.

\subsection{Statistical analysis}

Differences in baseline characteristics between study cohorts were evaluated among the controls using the chi-square test for categorical variables and the t-test for continuous variables. The chi-square test was used to determine if allele frequencies in healthy controls deviated from Hardy-Weinberg equilibrium. Conditional logistic regression for matched pairs was used to compute odds ratios for the relationship between VDR polymorphisms and risk of EOC. With the current study sample size and assuming minor allele frequencies of 35-45\% in the control group [10,18], we expected to have $80 \%$ power to detect odds ratios in the range of 0.56-0.58 in a priori calculations. Models including interaction terms between cohort and genotype and between age and genotype were compared to models excluding them, using the likelihood ratio test. Dominant, codominant, and recessive models were evaluated for each SNP as predictors of EOC risk. Potential ovarian cancer risk factors such as reproductive history (parity, number of full term pregnancies, and age at first full term pregnancy), age at menarche, menopausal status, oral contraceptive use, body mass index and smoking status were evaluated as covariates in the logistic regression models. However, the only variables significantly different between cases and controls were parity and oral contraceptive use (both categorized as ever/never). Therefore, multivariate models included only these two variables and the matching factors. Haplotypes were estimated from genotype data using PHASE version 2.1.1 (http://www.stat.washington.edu/stephens/phase.html) and odds ratios associated with 
having zero, one, or two copies of each individual haplotype were determined using conditional logistic regression. We used SAS software (version 9.1, SAS institute, Cary, NC) for statistical analyses.

\section{Results}

Table I shows the characteristics of the participants at baseline by participating cohort. Within the NSHDS cohort, controls were more likely to have had at least one full term pregnancy and taken oral contraceptives than cases ( $p=0.01$ and $p=0.03$, respectively). More controls in the NYUWHS cohort were premenopausal at baseline $(p=0.01)$, oral contraceptives users $(p=$ $0.03)$, mothers of at least one full-term child $(p<0.0001)$, former or current smokers $(p=0.01)$ and had reported an earlier age at menarche $(\mathrm{p}<0.0001)$ than NSHDS controls. Although there were no significant differences in genotype frequencies between cases and controls within cohorts, NYUWHS controls exhibited somewhat lower frequencies of the BSM1 A/A genotype than NSHDS controls $(p=0.06)$. Genotype frequencies, separately by cohort and in both cohorts combined, were consistent with previously published estimates for Caucasian populations [10]. Among the controls, genotype frequencies were in Hardy-Weinberg equilibrium ( $p>0.05$ for all SNPs) within each cohort and when all controls were combined.

Odds ratios for EOC associated with each VDR polymorphism in both cohorts are given in Table II. There were no statistically significant differences between cases and controls in any of the dominant, codominant or recessive SNP models. Additionally, the tests for interaction by cohort or age group were not significant and there were no cohort-specific associations between genotype and EOC risk.

Because genetic effects are not exerted individually, we considered the combined effects of the BSM1, APA1, and TAQ1 polymorphisms, which are in high linkage disequilibrium [12, 14], and may be associated with a functional variant on the VDR or another related gene [10]. FOK1 was not used to construct haplotypes because it is in linkage equilibrium with the other three SNPs and its inclusion resulted in a large number of uncommon haplotypes. Haplotype frequencies estimated for the three-SNP haplotypes using PHASE software are given in table III. Haplotype pair designations were assigned with a probability greater than $90 \%$ except for 6 participants who were assigned a 74\% probability of having their predicted haplotypes. Although PHASE did not readily permit estimating probability weights to incorporate into the regression model, these SNPs are in strong linkage disequilibrium and there are few potential haplotypes. Therefore, inclusion of uncertainty estimates are unlikely to alter the results [19]. Additionally, it has been shown that using an EM algorithm to estimate haplotypes from unphased VDR SNP genotype data was in complete concordance with haplotypes that were 'read' directly [20]. Haplotype pair assignments did not change over multiple runs of PHASE from different seed points, nor did the assignments change if the two cohorts' haplotypes were phased separately. Participants with one or more copies of a haplotype found in less than $1 \%$ of the population were grouped into a single "other" category. The odds ratios associated with having one or two copies of a given haplotype versus not having any copies of that same haplotype are given in table III. Although, there was a significant increase in risk of epithelial ovarian cancer for women with 1 copy of the GTT haplotype (OR $=1.56$; $95 \% \mathrm{CI}=1.02-2.38)$ this was not observed for women with two copies of the haplotype (OR $=0.62 ; 95 \% \mathrm{CI}=0.17-2.30)$. Grouping participants with one or two copies of the GTT haplotype attenuated the odds ratio ( $\mathrm{OR}=1.43 ; 95 \% \mathrm{CI}=0.95-2.16)$, indicating that the significant association with one copy of the haplotype is likely due to chance. Possessing one or two copies of GGT or ATC did not significantly alter risk of ovarian cancer. Addition of FOK1 genotype, parity, or oral contraceptive use to the haplotype models did not alter the regression coefficients. There was no significant interaction between FOK1 genotype and BSM1/APA1/TAQ1 haplotypes ( $\mathrm{p}$ for interaction > 0.05). When the two cohorts were 
considered separately, the odds ratios associated with copy number of each haplotype did not change appreciably.

\section{Discussion}

This is the one of the first studies to investigate the association between vitamin $\mathrm{D}$ receptor polymorphisms and risk of ovarian cancer. In this case control study nested within two prospective cohorts there were no significant differences in risk of epithelial ovarian cancer associated with genotype at any of these loci (BSMI, APAI, TAQI, and FOKI) in the VDR gene. To our knowledge, the only other study of vitamin $\mathrm{D}$ receptor polymorphisms and risk of ovarian cancer [11] reported an increased risk in women with the FOK1 T allele, especially for those with a history of oral contraceptive use.

Inconsistent results may be due to false positive results, population differences in allele frequencies, or variations in intake and/or conversion of vitamin D. Additionally, BSMI, APA1, and TAQ1 are 3' non-functional polymorphisms that may only be associated with risk of disease in some populations through linkage disequilibrium with another functional variant. The FOKI polymorphism is a more compelling candidate for association studies given the data demonstrating that the $\mathrm{CC}$ genotype results in a more active form of vitamin $\mathrm{D}$ receptor $[9$, 10]. However, we found no evidence for a role of this polymorphism in EOC.

The strengths of this study include its prospective design which minimizes survivor bias, the same source population of the cases and the controls in each cohort, which maximizes their comparability, and the completeness of follow-up, data collection, and case ascertainment.

Nevertheless, given the relatively low incidence of EOC in the general population, statistical power to detect main effects of VDR SNPs in 170 cases and 323 controls was limited. However, combining two cohorts at different geographic locations (USA and Sweden) should have somewhat improved the generalizability of our findings. Despite certain differences between the two cohorts, both showed an absence of a relationship between VDR SNPs and risk of epithelial ovarian cancer.

Although vitamin D receptor polymorphisms did not independently alter risk of epithelial ovarian cancer, it is possible that these genetic differences could modify risk in the context of circulating vitamin D derived from diet and sun exposure.

\section{Acknowledgments}

We thank the participants of the NYUWHS and the NSHDS, whose invaluable help and dedication made this project possible. We would like to thank Yelena Afanasyeva for database management, Diane Currie and Lorraine Maceda for technical assistance. We would also like to thank the Lion's Cancer Foundation at Umeå University, Sweden, for supporting this project.

Grant support: Primarily supported by research grant R03 CA096428 from the National Institutes of Health. The New York University Women's Health Study is supported by NIH grant R01 CA34588. The Northern Sweden Health and Disease Study is sponsored by the Swedish Cancer Society.

\section{References}

1. American Cancer Society. Cancer Facts \& Figures - 2007. Atlanta: American Cancer Society, Inc.; 2007.

2. Ford D, Easton DF, Peto J. Estimates of the gene frequency of BRCA1 and its contribution to breast and ovarian cancer incidence. Am. J. Hum. Genet 1995;57:1457-1462. [PubMed: 8533776]

3. Lefkowitz ES, Garland CF. Sunlight, vitamin D, and ovarian cancer mortality rates in US women. Int. J. Epidemiol 1994;23:1133-1136. [PubMed: 7721513]

4. Parkin DM, Bray F, Ferlay J, Pisani P. Global cancer statistics, 2002. CA Cancer J. Clin 2005;55:74108. [PubMed: 15761078] 
5. Freedman DM, Dosemeci M, McGlynn K. Sunlight and mortality from breast, ovarian, colon, prostate, and non-melanoma skin cancer: a composite death certificate based case-control study. Occup. Environ. Med 2002;59:257-262. [PubMed: 11934953]

6. Holick MF. Sunlight and vitamin D for bone health and prevention of autoimmune diseases, cancers, and cardiovascular disease. Am. J. Clin. Nutr 2004;80:1678S-1688S. [PubMed: 15585788]

7. Bouillon R, Eelen G, Verlinden L, Mathieu C, Carmeliet G, Verstuyf A. Vitamin D and cancer. J. Steroid Biochem. Mol. Biol 2006;102:156-162. [PubMed: 17113979]

8. Malloy PJ, Pike JW, Feldman D. The vitamin D receptor and the syndrome of hereditary 1,25dihydroxyvitamin D-resistant rickets. Endocr. Rev 1999;20:156-188. [PubMed: 10204116]

9. Arai H, Miyamoto K, Taketani Y, Yamamoto H, Iemori Y, Morita K, Tonai T, Nishisho T, Mori S, Takeda E. A vitamin D receptor gene polymorphism in the translation initiation codon: effect on protein activity and relation to bone mineral density in Japanese women. J. Bone Miner. Res 1997;12:915921. [PubMed: 9169350]

10. Uitterlinden AG, Fang Y, van Meurs JB, Pols HA, van Leeuwen JP. Genetics and biology of vitamin D receptor polymorphisms. Gene 2004;338:143-156. [PubMed: 15315818]

11. Lurie, G.; Wilkens, LR.; Thompson, P.; McDuffie, KE.; Carney, ME.; Terada, KY.; Goodman, MT. VDR gene polymorphisms and epithelial ovarian cancer risk; April 14-18; Poster No. 2605, AACR Annual Meeting; Los Angeles. 2007.

12. Morrison NA, Yeoman R, Kelly PJ, Eisman JA. Contribution of trans-acting factor alleles to normal physiological variability: vitamin D receptor gene polymorphism and circulating osteocalcin. Proc. Natl. Acad. Sci. USA 1992;89:6665-6669. [PubMed: 1353882]

13. Faraco JH, Morrison NA, Baker A, Shine J, Frossard PM. ApaI dimorphism at the human vitamin D receptor gene locus. Nucleic Acids Res 1989;17:2150. [PubMed: 2564666]

14. Morrison NA, Qi JC, Tokita A, Kelly PJ, Crofts L, Nguyen TV, Sambrook PN, Eisman JA. Prediction of bone density from vitamin D receptor alleles. Nature 1994;367:284-287. [PubMed: 8161378]

15. Toniolo PG, Pasternack BS, Shore RE, Sonnenschein E, Koenig KL, Rosenberg C, Strax P, Strax S. Endogenous hormones and breast cancer: a prospective cohort study. Breast Cancer Res. Treat 1991;18:S23-S26. [PubMed: 1873553]

16. Toniolo PG, Levitz M, Zeleniuch-Jacquotte A, Banerjee S, Koenig KL, Shore RE, Strax P, Pasternack BS. A prospective study of endogenous estrogens and breast cancer in postmenopausal women. J. Natl. Cancer Inst 1995;87:190-197. [PubMed: 7707406]

17. Hallmans G, Agren A, Johansson G, Johansson A, Stegmayr B, Jansson JH, Lindahl B, Rolandsson O, Soderberg S, Nilsson M, Johansson I, Weinehall L. Cardiovascular disease and diabetes in the Northern Sweden Health and Disease Study Cohort - evaluation of risk factors and their interactions. Scand. J. Public Health 2003;61:18-24.

18. The International HapMap Consortium. The International HapMap Project. Nature 2003;426:789796. [PubMed: 14685227]

19. Kraft P, Cox DG, Paynter RA, Hunter D, De Vivo I. Accounting for haplotype uncertainty in matched association studies: a comparison of simple and flexible techniques. Genet. Epidemiol 2005;28:261272. [PubMed: 15637718]

20. Thakkinstian A, D'Este C, Attia J. Haplotype analysis of VDR gene polymorphisms: a meta-analysis. Osteoporos. Int 2004;15:729-734. [PubMed: 15057510] 
Table I

Characteristics of invasive epithelial ovarian cancer cases and matched controls, NYUWHS and NSHDS cohorts

\begin{tabular}{|c|c|c|c|c|}
\hline \multirow{2}{*}{ Characteristic } & \multicolumn{2}{|c|}{ NYUWHS } & \multicolumn{2}{|c|}{ NSHDS } \\
\hline & Cases $(n=71)$ & Controls $(n=125)$ & Cases $(n=99)$ & Controls $(n=198)$ \\
\hline $\begin{array}{l}\text { Age at sampling, mean (SD), } \\
\text { years }\end{array}$ & $53(8.8)$ & $53(8.8)$ & $54(9.0)$ & $54(9.0)$ \\
\hline $\begin{array}{l}\text { Time to diagnosis }{ }^{a} \text {, mean } \\
\text { (SD), years } \\
\text { Unknown }\end{array}$ & $\begin{array}{l}6.9(3.5) \\
0\end{array}$ & & $\begin{array}{l}4.8(3.3) \\
2\end{array}$ & \\
\hline $\begin{array}{l}\text { BMI at sampling, mean (SD), } \\
\mathrm{kg} / \mathrm{cm}^{2} \\
\text { Unknown }\end{array}$ & $\begin{array}{l}25(4.1) \\
0\end{array}$ & $\begin{array}{l}26(4.4) \\
3\end{array}$ & $\begin{array}{l}26(4.1) \\
8\end{array}$ & $\begin{array}{l}26(4.2) \\
8\end{array}$ \\
\hline $\begin{array}{l}\text { Age at menarche }{ }^{b} \text {, mean (SD), } \\
\text { years } \\
\text { Unknown }\end{array}$ & $\begin{array}{l}12.3(1.5) \\
0\end{array}$ & $\begin{array}{l}12.7(1.5) \\
0\end{array}$ & $\begin{array}{l}13.6(1.4) \\
22\end{array}$ & $\begin{array}{l}13.4(1.5) \\
23\end{array}$ \\
\hline $\begin{array}{l}\text { Age at } 1^{\text {st }} \mathrm{FTP}^{c} \text {, mean }(\mathrm{SD}), \\
\text { years } \\
\text { Unknown }\end{array}$ & $\begin{array}{l}25(5.5) \\
0\end{array}$ & $\begin{array}{l}25(4.8) \\
0\end{array}$ & $\begin{array}{l}25(4.5) \\
3\end{array}$ & $\begin{array}{l}25(4.8) \\
0\end{array}$ \\
\hline $\begin{array}{l}\text { Menopausal status at } \\
\text { enrollment } b \text {, n (\%) } \\
\text { Premenopausal } \\
\text { Postmenopausal } \\
\text { Unknown }\end{array}$ & $\begin{array}{l}29(40.8) \\
42(59.2) \\
0\end{array}$ & $\begin{array}{l}52(41.6) \\
73(58.4) \\
0\end{array}$ & $\begin{array}{l}30(30.3) \\
69(69.7) \\
0\end{array}$ & $\begin{array}{l}53(26.9) \\
144(73.1) \\
1\end{array}$ \\
\hline $\begin{array}{l}\text { Parity, }{ }^{b d} \\
\text { Never } \\
\text { Ever } \\
\text { Unknown }\end{array}$ & $\begin{array}{l}28(39.4) \\
43(60.6) \\
0\end{array}$ & $\begin{array}{l}39(31.2) \\
86(68.8) \\
0\end{array}$ & $\begin{array}{l}18(22.2) \\
63(77.8) \\
18\end{array}$ & $\begin{array}{l}19(10.7) \\
159(89.3) \\
20\end{array}$ \\
\hline $\begin{array}{l}\text { OC use }^{b, d}, \mathrm{n}(\%) \\
\text { Never } \\
\text { Ever } \\
\text { Unknown }\end{array}$ & $\begin{array}{l}39(70.9) \\
16(29.1) \\
16\end{array}$ & $\begin{array}{l}63(68.5) \\
29(31.5) \\
33\end{array}$ & $\begin{array}{l}56(68.3) \\
26(31.7) \\
17\end{array}$ & $\begin{array}{l}93(55.0) \\
76(45.0) \\
29\end{array}$ \\
\hline $\begin{array}{l}\text { Smoking status }^{b}, \mathrm{n}(\%) \\
\text { Never } \\
\text { Ever } \\
\text { Unknown }\end{array}$ & $\begin{array}{l}25(40.3) \\
37(59.7) \\
9\end{array}$ & $\begin{array}{l}38(38.8) \\
60(61.2) \\
27\end{array}$ & $\begin{array}{l}53(60.9) \\
34(39.1) \\
12\end{array}$ & $\begin{array}{l}102(55.7) \\
81(44.3) \\
15\end{array}$ \\
\hline $\begin{array}{l}B S M I \text { genotype, n }(\%) \\
G / G(b b) \\
A / G(B b) \\
A / A(B B) \\
\text { Unknown }\end{array}$ & $\begin{array}{l}28(40.0) \\
36(51.4) \\
6(8.6) \\
1\end{array}$ & $\begin{array}{l}50(40.7) \\
61(49.6) \\
12(9.8) \\
2\end{array}$ & $\begin{array}{l}39(39.8) \\
40(40.8) \\
19(19.4) \\
1\end{array}$ & $\begin{array}{l}86(44.1) \\
75(38.5) \\
34(17.4) \\
3\end{array}$ \\
\hline $\begin{array}{l}\text { APAI genotype, n }(\%) \\
\text { T/T }(A A) \\
\text { T/G }(A a) \\
\text { G/G }(a a) \\
\text { Unknown }\end{array}$ & $\begin{array}{l}25(35.2) \\
37(52.1) \\
9(12.7) \\
0\end{array}$ & $\begin{array}{l}37(29.8) \\
58(46.8) \\
29(23.4) \\
1\end{array}$ & $\begin{array}{l}30(30.9) \\
43(44.3) \\
24(24.7) \\
2\end{array}$ & $\begin{array}{l}49(25.0) \\
94(48.0) \\
53(27.0) \\
2\end{array}$ \\
\hline $\begin{array}{l}T A Q I \text { genotype, n }(\%) \\
\text { T/T }(T T) \\
\text { T/C }(T t) \\
\text { C/C }(t t) \\
\text { Unknown }\end{array}$ & $\begin{array}{l}27(38.0) \\
35(49.3) \\
9(12.7) \\
0\end{array}$ & $\begin{array}{l}49(39.5) \\
58(46.8) \\
17(13.7) \\
1\end{array}$ & $\begin{array}{l}41(41.8) \\
40(40.8) \\
17(17.4) \\
1\end{array}$ & $\begin{array}{l}88(44.9) \\
75(38.3) \\
33(16.8) \\
2\end{array}$ \\
\hline $\begin{array}{l}\text { FOKI genotype, n }(\%) \\
\text { C/C }(F F) \\
\text { C/T }(F f) \\
\text { T/T }(f f) \\
\text { Unknown }\end{array}$ & $\begin{array}{l}27(38.0) \\
33(46.5) \\
11(15.5) \\
0\end{array}$ & $\begin{array}{l}51(40.8) \\
57(45.6) \\
17(13.6) \\
0\end{array}$ & $\begin{array}{l}39(40.2) \\
42(43.3) \\
16(16.5) \\
2\end{array}$ & $\begin{array}{l}69(35.2) \\
95(48.5) \\
32(16.3) \\
2\end{array}$ \\
\hline
\end{tabular}

\footnotetext{
${ }^{a}$ Differs significantly between NYUWHS and NSHDS cases at $\mathrm{p}=0.0001$.
} 
${ }^{b}$ NYUWHS and NSHDS controls differ significantly $(\mathrm{p}<0.05)$ with regard to age at menarche, menopausal status, parity, ever use of oral contraceptives, and smoking status.

${ }^{c}$ FTP, full term pregnancy; variable includes ever pregnant women only.

${ }^{d}$ Case-control differences significant only for NSHDS for parity $(\mathrm{p}=0.01)$ and for oral contraceptives use $(\mathrm{p}=0.03)$. 
Table II

Odds ratios for invasive epithelial ovarian cancer by vitamin D receptor genotypes

\begin{tabular}{|c|c|c|c|}
\hline Genotype (cases/controls) & Univariate OR $(95 \% \mathrm{CI})$ & $\begin{array}{c}\text { Univariate Restricted }^{a} \text { OR } \\
(95 \% \text { CI })\end{array}$ & Multivariate $^{b}$ OR $(95 \%$ CI $)$ \\
\hline $\begin{array}{l}\text { BSMI } \\
\text { G/G (67/136) } \\
\text { A/G (76/136) } \\
\text { A/A }(25 / 46)\end{array}$ & $\begin{array}{c}1.0 \\
1.11(0.73-1.69) \\
1.09(0.61-1.92) \\
\text { p-trend }=0.69\end{array}$ & $\begin{array}{c}1.0 \\
1.22(0.73-2.04) \\
1.15(0.59-2.27) \\
\text { p-trend }=0.58\end{array}$ & $\begin{array}{c}1.0 \\
1.20(0.71-2.04) \\
1.08(0.54-2.17) \\
\text { p-trend }=0.70\end{array}$ \\
\hline $\begin{array}{l}\text { APAI } \\
\text { T/T (55/86) } \\
\text { T/G (80/152) } \\
\text { G/G (33/82) }\end{array}$ & $\begin{array}{c}1.0 \\
0.87(0.57-1.33) \\
0.67(0.40-1.11) \\
\text { p-trend }=0.13\end{array}$ & $\begin{array}{c}1.0 \\
1.01(0.60-1.72) \\
0.71(0.38-1.33) \\
\text { p-trend }=0.31\end{array}$ & $\begin{array}{c}1.0 \\
1.00(0.58-1.73) \\
0.67(0.35-1.26) \\
\text { p-trend }=0.22\end{array}$ \\
\hline $\begin{array}{l}\text { TAQI } \\
\text { T/T (68/137) } \\
\text { T/C (75/133) } \\
\text { C/C }(26 / 50)\end{array}$ & $\begin{array}{c}1.0 \\
1.13(0.74-1.71) \\
1.07(0.61-1.86) \\
\text { p-trend }=0.71\end{array}$ & $\begin{array}{c}1.0 \\
1.19(0.71-2.00) \\
1.06(0.55-2.06) \\
\text { p-trend }=0.74\end{array}$ & $\begin{array}{c}1.0 \\
1.21(0.71-2.06) \\
0.98(0.50-1.94) \\
\text { p-trend }=0.87\end{array}$ \\
\hline $\begin{array}{l}\text { FOKI } \\
\text { C/C (66/120) } \\
\text { C/T (75/152) } \\
\text { T/T }(27 / 49)\end{array}$ & $\begin{array}{c}1.0 \\
0.91(0.62-1.34) \\
1.03(0.59-1.81) \\
\text { p-trend }=0.91\end{array}$ & $\begin{array}{c}1.0 \\
1.11(0.68-1.81) \\
1.20(0.60-2.41) \\
\text { p-trend }=0.57\end{array}$ & $\begin{array}{c}1.0 \\
1.10(0.67-1.81) \\
1.23(0.61-2.51) \\
\text { p-trend }=0.55\end{array}$ \\
\hline
\end{tabular}

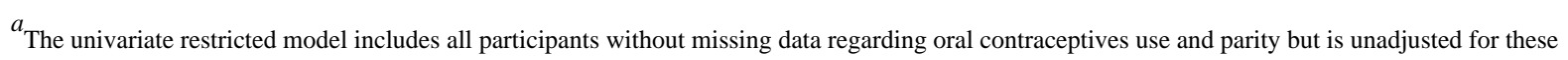
factors.

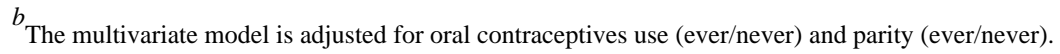

Note: All models adjusted for matching factors (e.g., cohort, age at entry (within 6 months), date of blood donation (within 15 days), and number and dates of subsequent blood donations, if any). 
Table III

Haplotype frequencies and odds ratios of epithelial ovarian cancer by haplotypes

\begin{tabular}{|c|c|c|c|c|}
\hline $\begin{array}{l}\text { Haplotype Copies } \\
(B S M I, \text { APAI, TAQI) }\end{array}$ & Cases n (\%) & Controls n (\%) & OR $(95 \% \text { CI })^{a}$ & $p$ for trend \\
\hline \multicolumn{5}{|l|}{ GGT } \\
\hline 0 & $57(33.5)$ & $91(28.2)$ & Reference & \\
\hline 1 & $80(47.1)$ & $154(47.7)$ & $0.87(0.57-1.32)$ & \\
\hline 2 & 33 (19.4) & $78(24.2)$ & $0.72(0.43-1.19)$ & 0.20 \\
\hline \multicolumn{5}{|l|}{ ATC } \\
\hline 0 & $72(42.4)$ & $146(45.2)$ & Reference & \\
\hline 1 & $75(44.1)$ & 134 (41.5) & $1.15(0.76-1.75)$ & \\
\hline 2 & $23(13.5)$ & $43(13.3)$ & $1.11(0.61-1.99)$ & 0.61 \\
\hline \multicolumn{5}{|l|}{ GTT } \\
\hline 0 & $114(67.1)$ & 241 (74.6) & Reference & \\
\hline 1 & $53(31.2)$ & $72(22.3)$ & $1.56(1.02-2.38)$ & \\
\hline 2 & $3(1.8)$ & $10(3.1)$ & $0.62(0.17-2.30)$ & 0.22 \\
\hline
\end{tabular}

${ }^{a}$ All models adjusted for matching factors (e.g., cohort, age at entry (within 6 months), date of blood donation (within 15 days), and number and dates of subsequent blood donations, if any). 